\title{
Battling Deforestation in Brazil: Implementing a REDD Framework to Combat Global Climate Change
}

\author{
By Helaina Matza
}

Much international attention has focused on how deforestation has contributed to overall carbon dioxide output, thereby exacerbating global climate change. This paper will focus specifically on Brazil's current efforts to combat deforestation and the suggested modifications to the design and future implementation of programs based on the United Nations' Reducing Emissions from Deforestation and Forest Degradation (REDD) framework in Brazil.

\section{Introduction}

Recent studies estimate that deforestation contributes up to 30 percent of global carbon dioxide emissions to the atmosphere annually (Johnson 2009). In response to climate and other environmental concerns, policymakers in Brazil have sought ways to slow the pace of deforestation. However, there is concern that a change in Brazil's politics in the direction of favoring agribusiness interests could lead to stalled efforts in combatting deforestation. To advance action related to deforestation reversal, Brazilian government officials should continue to consider international climate change mitigation initiatives related to reducing carbon dioxide emissions, in conjunction with their own national economic development, equity, and impact issues.

The United Nations' Reducing Emissions from Deforestation and Forest Degradation (REDD) model is a framework established to mitigate carbon emissions that contribute to climate change through the prevention of deforestation and through reforestation efforts. REDD establishes financial incentives for changing the way forest resources are used (International Institute for Environment and Development 2009). Coupled with local community participation and surveillance measures, programs structured on the REDD framework are viable options for battling deforestation in Brazil, which would strengthen the Brazilian government's efforts and lead to a reduction in carbon dioxide emissions, ultimately combatting global climate change.

To illustrate this point, this paper will first explore deforestation's role in contributing to global climate change, followed by an examination of the role forestry policy plays in preventing or exacerbating deforestation. The paper will then discuss the development of the REDD framework and how it is designed to function. It will then review Brazil's current efforts and challenges in implementing a national REDD program in an attempt to reverse decades of deforestation. To assist in analyzing Brazil's efforts, the paper reviews Panama's experience in implementing REDD programs to address the issue of deforestation. Finally, this paper will analyze Brazil's situation in the context of the policies discussed and Panama's experiences and will make policy recommendations on potential best practices that Brazilian policymakers should take into consideration to strengthen and expand the implementation of Brazil's deforestation programs. 


\section{Deforestation's Role in Global Cli- mate Change}

Deforestation is a major contributing factor to the increases in worldwide greenhouse gas emissions each year. A report from the United Nations' Food and Agriculture Organization demonstrates that the greatest overall loss to forests is occurring in Central and South America, followed by Africa (2009). The study cites experts who argue that efforts to reduce carbon dioxide emissions, focused on other sectors alone, such as carbon emissions from industrial production, would be more expensive and take twice as long if not coupled with a decrease in deforestation (2009). Additionally, curtailing the deforestation rates in Brazil and Indonesia alone could achieve 80 percent of the total emissions reductions required under the Kyoto Protocol (Johnson 2009). Therefore, reducing global carbon emissions would be a far more herculean task if deforestation were not addressed in a significant way.

\section{The Dynamics of Deforestation and Forestry Policy}

The major factors that contribute to deforestation include the exploitation of forests through expanding populations, logging, agriculture, and biofuel production (Nabuurs 2007). An Intergovernmental Panel on Climate Change report concludes that the most sustainable forestry policies would maintain or increase forest carbon stock-the amount of carbon that is stored in a living forest that would otherwise be released into the atmosphere as carbon dioxide-while protecting a country's national interest in maintaining timber yields and agriculture land (2007). This type of forestry policy recognizes that the call for slowing the rate of deforestation must be balanced with the need to provide enough timber and agricultural land to meet national and global consumption requirements. In an effort to balance competing interests - such as the interests of farmers as compared to those of conservationists - the international community has designed frameworks that provide compensation to stakeholders for their economic opportunity costs related to forgoing logging or agriculture in order to preserve forests.

\section{Developing the REDD Framework}

There has been significant international progress related to climate change mitigation strategies over the last 15 years, starting with the 1997 Kyoto Protocol and leading to the current REDD framework. One example of this progress, the Copenhagen Accord, emanated from the 2009 Copenhagen Climate Change Conference and outlined improvements to the Kyoto Protocol's Clean Development Mechanism. This is the mechanism by which countries subject to emissions limits under the Kyoto Protocol can create emission reduction initiatives in developing countries in order to earn emissions credits (UN Kyoto Protocol 1998). The Copenhagen Accord includes several agreements between representatives of countries from around the world. One such agreement is the overall goal of restricting the maximum global average temperature increase to no more than two degrees Celsius above preindustrial levels. Additionally, through the Copenhagen Accord, a group of countries committed to providing funds for climate change mitigation in the range of US $\$ 30$ billion for the period 2010 to 2012, while financing an additional US $\$ 100$ billion per year by 2020 (United Nations Secretariat 2010). In addition, since 2009, the United Nations Framework Convention on Climate Change has continued to make commitments for mitigating climate change with the 2010 Cancun agreements and with the 2011 Durban Platform for Enhanced Action (UNGA Resolution, The Future We Want 2012).

In 2012, the outcome of the Rio+20 United Nations Conference on Sustainable Development reaffirmed the country-participants' desires to confront the numerous causes and results of global 
climate change. The conference resulted in a draft United Nations resolution titled "The Future We Want," which refers to climate change in dozens of contexts as a major factor in the world's economic and environmental future (2012). The draft United Nations resolution reflects an international understanding regarding the value of forests in economic and environmental terms and reaffirms the link between forest degradation and global climate change (2012).

The Rio+20 Conference also resulted in commitments for sustainable development projects totaling US $\$ 513$ billion from a combination of governments, nongovernmental organizations (NGOs), and companies (UN News Centre 2012). One such commitment is a partnership between a private company and two NGOs to help landowners in Brazil reforest their land in an effort to reforest 5,00o hectares of the Atlantic Rainforest biome by the end of 2017 (Aborem 2011). This commitment displays the potential role international partnerships and efforts can play in reversing deforestation and preventing climate change.

While some critics of the aforementioned international agreements and conferences contend that they frequently fail to outline sufficient specifics to enact meaningful change (Prada 2012), such conferences and international efforts do demonstrate the global commitment to combatting global warming. Similar international attention and collaboration led to the initial development of the REDD framework, which was established by the United Nations in 2008. The framework provides a platform for experimentation and action on reducing forest degradation and decreasing carbon dioxide emissions.

Since its creation, the REDD framework has continuously been modified and enhanced as partnerships and commitments are established in both the developed and developing worlds. REDD projects attempt to create a monetary value for the carbon stored in forests. Inter- national organizations and donor nations may offer financial incentives for developing countries to reduce carbon emissions from deforestation and invest in lowcarbon activities. "REDD+" goes further by looking beyond deforestation and forest degradation to promote conservation, sustainable management of forests, and increasing carbon storage by preserving tree stocks (Secretariat of the UNFPII 2011). For the purposes of this paper, any reference to REDD programs means REDD and/or REDD+ because REDD+ has enveloped much of the original REDD framework.

In 2009, the European Union proposed a three-step process for REDD development that has since been integrated into the REDD framework. The overall REDD strategy focuses on 1) readiness of developing countries to set up the infrastructure necessary to implement a REDD program, 2) designing each developing country's individual national REDD strategy, often supported directly through international public finance and 3) using a performance-based financial mechanism established under the United $\mathrm{Na}$ tions Framework Convention on Climate Change to create economic incentives to reduce deforestation (Swedish Presidency of the European Union 2012). Table 1 outlines the three-phase implementation process in greater detail in terms of outcomes, safeguards, finance mechanisms, and triggers/eligibility criteria.

Currently, the UN-REDD programme has a multidonor trust fund to finance developing country activities, valued at US\$112 million in 2010, as shown in Table 2 (United Nations Development Group 2010). However, there are still concerns related to the viability and capacity of the UN-REDD programme. There has been some discussion about whether financial mechanisms for the REDD programme should be fund-based or marketbased. A fund-based system would compensate developing countries that reduce carbon emissions with money from a gen- 
Table 1: Operational Framework for REDD Implementation

\begin{tabular}{|c|c|c|c|}
\hline & $\begin{array}{l}\text { Phase 1: } \\
\text { Preparation and } \\
\text { Readiness }\end{array}$ & $\begin{array}{l}\text { Phase 2: } \\
\text { Policies and Measures }\end{array}$ & $\begin{array}{l}\text { Phase 3: } \\
\text { Performance-based } \\
\text { Payments }\end{array}$ \\
\hline Outcomes & $\begin{array}{l}\text {-Development of nation- } \\
\text { al REDD-plus strategies } \\
\text {-Assessment of drivers of } \\
\text { deforestation } \\
\text {-Clarification of rights } \\
\text {-Institutional development } \\
\text {-Demonstration activities } \\
\text {-Deployment of multi- } \\
\text { stakeholder processes }\end{array}$ & $\begin{array}{l}\text {-Development of na- } \\
\text { tional portfolios } \\
\text {-Benefit-sharing and } \\
\text { equitable distribution } \\
\text {-Development of } \\
\text { institutional capacity, } \\
\text { strengthening of forest } \\
\text { governance, and accom- } \\
\text { plishment of land-tenure } \\
\text { reform }\end{array}$ & $\begin{array}{l}\text {-Third-party-verifiable } \\
\text { emissions reductions } \\
\text { and carbon-stock en- } \\
\text { hancements } \\
\text {-Equitable distribution } \\
\text { mechanisms } \\
\text {-Social and environ- } \\
\text { mental impact assess- } \\
\text { ment }\end{array}$ \\
\hline Safeguards & $\begin{array}{l}\text { Transparency } \\
\text { Participation and } \\
\text { representation } \\
\text { - Particular attention to } \\
\text { women and most- vul- } \\
\text { nerable poor }\end{array}$ & $\begin{array}{l}\text { Social and environ- } \\
\text { mental audits } \\
\text { - Governance and legal- } \\
\text { ity audits } \\
\text { - Free, prior and in- } \\
\text { formed consent } \\
\text { - Installation of MRV } \\
\text { system }\end{array}$ & $\begin{array}{l}\text {. Free, prior and in- } \\
\text { formed consent } \\
\text { - Social and environ- } \\
\text { mental audits }\end{array}$ \\
\hline $\begin{array}{l}\text { Finance } \\
\text { Mechanisms }\end{array}$ & $\begin{array}{l}\text { - Multilateral and bilat- } \\
\text { eral grants } \\
\text { - Mechanisms such as } \\
\text { FCPF and UN-REDD } \\
\cdot \text { Voluntary carbon } \\
\text { markets } \\
\cdot \text { Public-sector and } \\
\text { private-sector funding }\end{array}$ & $\begin{array}{l}\text { The application of all } \\
\text { possible financial tools } \\
\text { within a portfolio frame- } \\
\text { work } \\
\cdot \text { Scaled-up public- sec- } \\
\text { tor and private- sector } \\
\text { investments } \\
\cdot \text { Implementation of } \\
\text { equitable distribution } \\
\text { mechanisms }\end{array}$ & $\begin{array}{l}\text { - Compliance market } \\
\text { - Non-market compli- } \\
\text { ance } \\
\text { - Underwriting risk } \\
\text { - Equitable distribution } \\
\text { mechanisms }\end{array}$ \\
\hline $\begin{array}{l}\text { Triggers/ } \\
\text { eligibility } \\
\text { criteria }\end{array}$ & $\begin{array}{l}\text { Multi-stakeholder } \\
\text { endorsement } \\
\text { - Development of plan } \\
\text { for overcoming gover- } \\
\text { nance and policy gaps }\end{array}$ & $\begin{array}{l}\text { - Adequate legal rights } \\
\text { and tenure systems } \\
\text { - Endorsement of ben- } \\
\text { efit distribution } \\
\text { - National capacity to } \\
\text { perform third-party } \\
\text { auditing } \\
\text { - Proxy indicators }\end{array}$ & \\
\hline
\end{tabular}

Source: TFD Review 2010.

eral fund created by donor nations. A market-based system would create incentives for carbon reduction through the creation of a carbon credit market. Countries could then earn credits through reduction of carbon emissions, which they could then sell to countries that desire to exceed their carbon emissions targets (Johnson 2009).

An additional concern about the REDD programme is how measurement, verification, and reporting should be conducted, all of which could ultimately increase the transaction costs of REDD financial mechanisms (2009). Professors Lee Alston and Krister Andersson of the University of Colorado identify the hidden transaction costs of offering financial incentives to encourage conservation, and point out that for REDD interventions to be successful, policymakers need to 
Table 2: Funding of UN-REDD Programme

\begin{tabular}{|c|l|l|}
\hline Funding partner & \multicolumn{1}{|c|}{ US dollars (in millions) } & \multicolumn{1}{c|}{ Time period } \\
\hline \multirow{2}{*}{ Norway } & 52.2 (committed) & $2008-2009$ \\
\cline { 2 - 3 } & 32.1 (committed) & 2010 \\
\hline \multirow{2}{*}{ Denmark } & 2.0 (committed) & 2010 \\
\cline { 2 - 3 } & 6.0 (pledged) & 2011 \\
\hline Spain & 20.2 (pledged) & $2010-2012$ \\
\hline Total & $\mathbf{1 1 2 . 5}$ & \\
\hline
\end{tabular}

Source: UN-REDD Programme 2011.

have a better understanding of transaction costs associated with these interventions (2009). The core challenge is finding ways to compensate landowners, governments, and indigenous tribes for foregoing the opportunities associated with clearing forests for agricultural use or timber (2009). Since transaction costs affiliated with monitoring and enforcing conservation are difficult to eliminate, Alston and Andersson suggest that REDD architects craft policy responses for each type of activity and with specific target areas that would be less expensive to implement (2009).

Alston and Andersson go on to posit that REDD would have a higher likelihood of success if REDD projects encourage multilevel governance support in monitoring and enforcing contracts (2009). This support includes participation by not only national governments and agencies, but also local organizations that have an active stake in the outcome of the project (2009). Additionally, there is belief among some in the international community that REDD activities should preserve biodiversity, not conflict with the lives of indigenous peoples, and contribute to sustainable development at the local level (Swedish Presidency of the European Union 2012).

The following section provides an example of how Panama has adopted the REDD framework, and reviews lessons learned that can be applied to Brazil as the country prepares to launch its national
REDD program.

\section{Case Study: Panama's Experience with the REDD Program}

Panama is one of 16 countries currently receiving funding through the UNREDD Programme (UN-REDD National Programmes 2012). Although a much smaller country than Brazil, Panama's tropical climate and development concerns are similar enough to Brazil's to render it a useful case study.

While preparing to implement REDD policies, Panama identified a number of implementation challenges including: a lack of capacity for investment monitoring; little coordination between agencies; government weakness in implementing national policies at the local level; absence of a clear legal framework to execute REDD programs; scant public awareness of the benefits of conserving the forest cover; economic marginalization of the communities that live in forests; and difficulty defining carbon ownership for indigenous and non-indigenous communities, clear land tenure, or a benefit distribution system (United Nations Development Programme 2008).

In an attempt to address these issues, Panama designed a comprehensive strategy that aimed to allow for economic growth and, at the same time, promote social well-being, participation, and conservation of natural resources. REDD provides financing that gives each participating country resources for social investment through social participation mecha- 
nisms. These mechanisms are designed to provide resources to local community organizations and businesses, which are in turn required to directly maintain environmental conditions. The government has made efforts to consult with indigenous and minority populations to account for all stakeholders, and the government is designing policies to include feedback and protection of these communities in the development of financial distribution mechanisms (Boucher 2010).

Additionally, Panama has placed a high priority on the creation of protected areas as a complement to the aforementioned community incentive program (United Nations Development Programme 2008). However, a 2009 study of nine protected areas in Panama examined the nation's ability to avoid deforestation and found that a government-mandated resource management approach involving restrictions and government-managed protected areas ended up marginalizing poor populations and encouraging natural resource depletion (Oestreicher 2009). Ultimately, the study found that the most successful protected areas were managed at the local level with support and coordination among national, international, and public institutions (2009).

According to the 2011 UN-REDD Year in Review Report, Panama has received US\$5.3 million in REDD funding to be disseminated from 2011 to 2014 . The report notes that Panama has made good progress at all levels in building institutional capacity for implementing its national program, including the development of a consultation process with indigenous populations. Monitoring, reporting, and verification capabilities were also strengthened through the use of satellite images to create a forest and vegetation map, as well as by agreeing on the overall structure of Panama's national forest and carbon monitoring system (UN-REDD Programme, 2011 Year in Review). Panama's success in the aforementioned areas suggest that implementing a national

\section{REDD program could work in Brazil. \\ Background: Combatting Deforesta- tion in Brazil}

Brazil has experienced high levels of tropical forest clearing throughout its past (The REDD Desk 2011). Agribusiness accounts for over 22 percent of Brazil's GDP (Government of Brazil, Ministry of Agriculture 2013), and the growing agribusiness sector has led to a large expansion of the agricultural frontier in the Amazon region (Börner 2008). In recent months, there has been concern among conservationists that Brazil's Forest Code, a piece of environmental legislation that has been in effect for 47 years, is insufficient to combat deforestation. The current discussion around this legislation reveals a vast disconnect between citizen support for Amazon conservation and the government's support of private agricultural interests (Barrionuevo 2012). On one hand, the general population in Brazil is supportive of preventing deforestation, while on the other, agriculture interests hold a great deal of sway over lawmakers (2012).

Between 2005 and 2010, Brazil made progress in addressing deforestation issues. At the 2009 United Nations Climate Change Conference, Brazil announced its National Plan on Climate Change (NPCC) aimed at reducing greenhouse gas emissions. The plan targets an 80 percent reduction in deforestation in the Amazon region by 2015 (The REDD Desk 2011).

Prior to announcing the plan in 2009, Brazilian President Luiz Inácio Lula da Silva had announced Brazil's commitment to reduce Amazon deforestation 80 percent below its historic baseline over the next 10 years (The REDD Desk 2011). To support this goal, Brazil created the Amazon Fund, supported by an initial pledge of US $\$ 1$ billion from the government of Norway. The first payment of US\$110 million was made in 2009 (Union of Concerned Scientists, 2011). More recently, Germany donated US\$29 million to the fund (The REDD Desk 2011). The Amazon 
Fund focuses on investing in law enforcement, protection of forest reserves, and the sustainable development of the Amazon region. It is also seeks to demonstrate the effectiveness of REDD policies in an effort to attract additional funding (Zadek 2010). Similarly, Brazil initiated the Juma Sustainable Development Reserve Project, which gave financial incentives to families that continued their agricultural activity without increasing deforestation (IDESAM 2008).

In 2010, Brazil's Ministry of the Environment led the process to begin construction of a national REDD strategy. Early stages of this process engaged stakeholders from all sectors of Brazilian society and included substantial participation from civic organizations (The REDD Desk 2011). At the national level, the REDD strategy will follow the baseline methodology used by the Amazon Fund and each individual initiative will use projected and historic baselines. According to the REDD program overview by the United Nations, Brazil's REDD framework does not have a formal system of safeguards at the national or state level (2011). The report outlines Brazil's current capacity to monitor deforestation through PRODES, a financial incentive program focused on wastewater processing, which can support further local level policy development and land tenure regulations. Finally, the current legal framework includes a series of mechanisms including the National Plan on Climate Change, the Plan for Prevention and Control of Deforestation in the Amazon and other proposals in the agricultural sector. At the national level, the National Plan on Climate Change sets sectorial emission reduction targets for Brazil to reduce deforestation in the Amazon by 80 percent by 2020 . Combined, the aforementioned plans and policies establish integrated actions for a national REDD strategy (2011).

Brazil is currently designing a national REDD program to further address the multifaceted challenges it faces in reaching its goal to reduce the net loss of forest coverage (The REDD Desk 2011). As part of the REDD program development process, Brazil has identified several areas where it will direct its deforestation efforts (Keller, interview, 2012). The first area is the push to control illegal logging in the country. Although logging has declined by 50 percent from 1998 to 2008, the government is presently working on strategies to properly govern and promote less lawlessness in frontier areas (Wallace 2012). The second area is related to the government's effort to promote reporting and monitoring of deforestation. This effort is important from a societal perspective, as Brazilian citizens are becoming increasingly concerned about the implications related to land use and conversion. State and municipal officials are taking strides to regulate land ownership with support from NGOs in sorting land titling (Keller, interview, 2012).

While Brazil has made efforts over the last 10 years to slow the annual rate of deforestation, it still faces challenges in balancing its economic development goals with deforestation initiatives. Discussion surrounding the Forest Code demonstrates that there are still mixed views throughout the country regarding land use. The previous administration originally supported dramatic land use reforms as outlined in the 2008 National Plan on Climate Change. Now, the current administration is bowing under pressure to reform the Forest Code to support agribusiness interests (Barrionuevo 2012). In a time when the Brazilian government's support is uncertain, a deforestation strategy with clearly defined international support and funding mechanisms may be the only reliable method of ensuring deforestation mitigation.

\section{Lessons from Panama's REDD Expe- rience}

Brazil faces many of the same challenges as Panama in combating deforestation. Similarly to Panama, Brazil's 
attempt at traditional command-and-control policies, such as national mandates without local engagement, have not been effective in combating deforestation. Brazil's REDD strategy should address both the economic and political drivers of deforestation by focusing on the incentives to both the government and individuals to confront deforestation.

In review of REDD policies and critiques, there is popular consensus that countries should use a participatory approach in designing their strategies (UNREDD Programme, Go REDD+ 2012). Panama consulted with indigenous and minority groups in identifying the appropriate avenues to funnel resources. Brazil has already attempted to consult with indigenous and minority groups during its REDD readiness phase and through state-level administration of REDD programs. In addition, Brazil held a series of multi-stakeholder dialogues, which boasted significant civil society participation. If Brazil continues these efforts, it may be able to consolidate one of the key components of an effective national REDD program: inclusion of local and indigenous stakeholders.

In regard to enforcement of landowner conservation commitments, Brazil can learn from Panama, and other REDD program countries as well, that local efforts for ensuring accountability are far more effective than top-down enforcement efforts. Solely topdown approaches to program implementation have not proven to be successful (Griffiths 2009). Brazil already has significant institutional capacity and many NGOs operating on the ground level (IDESAM 2008). Although Brazil has consulted with stakeholders during the initial design stage of its national REDD strategy, there should be continued dialogue with all groups. Projects like the Juma Sustainable Development Reserve Project were largely successful in preserving forests because of local monitoring and enforcement. Although a national framework is necessary for disseminating financing, implementation and enforcement should be done at the local level in order to ensure compliance. The Panama experience shows that program enforcement at the local level helped to ensure accountability and encourage greater responsiveness to all stakeholder needs (Lele 2000). Recipients of financial incentives will be less likely to renege on their responsibilities if monitoring is done locally (2000). Additionally, at the local level, programs can better account for the nuances and specific land use issues of a particular region or community. This element is especially necessary in a country like Brazil, where land ownership is often unclear and flagrant lawlessness pervades frontier areas (2000).

\section{How Brazil Should Model its National REDD Program}

Although Brazil has made significant commitments to slowing deforestation in recent years, a comprehensive REDD national strategy can help address the challenges the country faces in ensuring the sustainability of forest protection policies while taking into consideration prosperity for all stakeholders.

A recent cost assessment of REDD policies confirms that REDD programs could be a cost-effective way to reduce deforestation in Brazil (Börner 2008). To achieve these cost efficiencies, REDD policies should be implemented in Brazil with a focus on: infrastructure expansion; inclusion of stakeholders from national and local governments, citizens, and business sectors; and with an understanding of Brazilian agricultural land demand (2008).

Brazil is a prime candidate for a national REDD program due to the infrastructure and legal capacity already in place. The Amazon Fund and state-level REDD strategies in Brazil have been successful in bringing financial support for initial deforestation initiatives and have helped to slow down the overall deforestation rate (Zadek 2010). Brazil has also demonstrated institutional capacity through projects such as the Amazon 
Fund and the Juma Sustainable Development Reserve Project (IDESAM 2008). Funding for REDD initiatives has generally been administered through bilateral and federal government resources (The REDD Desk 2011). Additional funding for a unified REDD national framework could assist Brazil in realizing its goals of reducing deforestation by further bolstering its already established collaborative networks and providing financial incentives for forest preservation. According to Alston and Andersson (2009), implanting REDD strategies where they will most likely be successful (e.g. in a country such as Brazil with already established programs such as the Amazon Fund) is a good approach for ensuring that REDD programs are successful in reducing deforestation rates.

Brazil's diverse interests, including indigenous communities and agribusiness, need to be represented in deforestation strategies through incentives and compensation for opportunity costs associated with forgoing deforestation, thereby preserving and protecting forests. Focusing on practices that provide incentives for avoiding deforestation and for participating in reforestation efforts should be a component of a national REDD program in Brazil. Compensating both landowners for reforesting their land and agribusiness for practicing sustainable land use could provide the necessary incentives for participants in the agricultural industries in Brazil to responsibly manage their land. A comprehensive REDD strategy in Brazil should identify stakeholder needs and establish mechanisms for proper enforcement of conservation commitments.

Ultimately, continuing deforestation reduction efforts in Brazil through REDD initiatives will further international goals of mitigating carbon emissions from deforestation as well as the interests of those wanting to preserve the rainforest. There are market implications for Brazil if it chooses to reverse its reforestation efforts. Consumers are increasingly con- scious of avoiding products from deforested areas and, therefore, Brazil cannot afford to appear to be insensitive toward deforestation (Preston 2010). A national REDD program in Brazil can ensure international interests in curbing carbon emissions by encouraging sustainability of Brazil's progress, thusly protecting Brazil's export sector.

\section{Policy Recommendations}

Brazil's national REDD program should include input from many stakeholders to ensure a balanced approach that respects the economic well-being of those who rely on forestry for their living. A centralized financial mechanism that is funded from a variety of sources could help to ensure the sustainability of funding resources. These funding sources should include the Amazon Fund, the UNREDD Programme, Brazil's national government, NGOs, and individual donors. A portion of the funding can then be used to implement local-level monitoring and enforcement mechanisms. As this paper has shown, it is advisable that centralized funding be disseminated at the local level as case studies have demonstrated that control and accountability of a fund recipient increase with local-level monitoring and enforcement.

Indigenous populations should also be included in program design and implementation. Generally, indigenous groups frequently contribute to largescale land abuse and should be encouraged to maintain the land they live on. Increased enforcement at the local level will help ensure that indigenous populations are not displaced from their land.

Funding should also be allocated to invest in the development of safeguards at the national and state levels. The best safeguards will eventually grow to include a formalized measurable, reportable, and verifiable system and government-sponsored audits. In the early stages of development, NGO support will be critical in administering audits and providing data 
that can be used for performance evaluations.

In order to continue to promote economic growth, Brazil's national REDD program should include reforestation incentives for agribusiness. Financial incentives could encourage mid- to small-scale agribusiness to preserve land quality and reforest portions of their land, which could help sustain the health of the country's agribusiness sector while realizing the goals of the broader national forestry strategy.

\section{Conclusion}

Over the last 10 years, Brazil has made various efforts with its deforestation mitigation strategies; however, the future of these efforts remains uncertain as the country's Forest Code is currently in the process of being modified. Establishing a national REDD program in Brazil can be successful in increasing institutional capacity and funneling additional funding opportunities to the country's deforestation projects. Taking into consideration the stakeholders affected by deforestation reduction policies, in combination with designing mechanisms for community participation and local-level management, will greatly influence the quality and longevity of Brazil's deforestation mitigation policies.

\section{References}

Agritours Brasil. 2012. "Brazilian Agribusiness: Evolution, Challenges and Prospects." Accessed April 2, 2012. http://www.agritoursbrasil.com.br/brazilian_agribusiness.html.

Alston, Lee J., and Krister Andersson. 2009. "Why Governments Often Fail to Protect Forests: The Hidden Costs of Intervention.” Accessed January 16, 2013. http:// sobek.colorado.edu/ anderssk/Alston_Andersson_REDD_nov11.pdf.

Arborem. 2011 "Reforesting Brazil's Biomes \& Facilitating Biodiverse Genomic Flow between Atlantic Rainforest fragments." Commitment made at United Nations Conference on Sustainable Development Rio+20. Accessed August 23, 2012. http://www.uncsd2012.org/index.php?page=view\&nr=300\&type=1006\&me $\mathrm{nu}=36$.

Barrionuevo, Alexei. 2012. "In Brazil, Fears of a Slide Back for Amazon Protection.” The New York Times, January 24. Accessed April 4, 2012. http://www.nytimes. com/2012/o1/25/world/americas/in-brazil-protection-of-amazon-rainforesttakes-a-step-back.html?pagewanted=all\&_r=o.

Börner, J. and S. Wunder. 2008. "Paying for avoided deforestation in the Brazilian Amazon: from cost assessment to scheme design." International Forestry Review 10.1: 496-51. http://www.cifor.org/publications/pdf_files/articles/AWundero801.pdf.

Boucher, Doug, comp. 2011. "Tropical Forests and Climate: Brazil's Success in Reducing Deforestation.” Union of Concerned Scientists. Accessed ? Accessed August 23, 2012. http://www.ucsusa.org/assets/documents/global_warming/Brazils-Success-in-Reducing-Deforestation.pdf.

Brooks, Bradley. 2011. "Saving the Amazon from the Floor Up." Associated Press, December 10. Accessed March 26, 2012. http://cnsnews.com/news/article/saving-amazon-forest-floor.

Food and Agriculture Organization of the United Nations, 2009. "State of the World's Forests." Accessed March 20, 2013. ftp://ftp.fao.org/docrep/fao/o11/io350e/io350e.pdf.

Government of Brazil, Inter-ministerial Committee on Climate Change. 2008. "National Plan on Climate Change: Executive Summary, Decree No. 6263 of November 21, 
2007.” Accessed April 4, 2012. http://www.mma.gov.br/estruturas/208/_arquivos/national_plan_208.pdf.

Government of Brazil, Ministry of Agriculture, Livestock and Supply. 2013. "Strategic Sectors.” Accessed March 20, 2013. http://www.brasil.gov.br/para/invest/strategicsectors/farming/br_model1?set_language=en.

Griffiths, Tom. 2009. "Seeing 'REDD’? Forests, climate change mitigation and the rights of indigenous peoples.” unfccc.int/resource/docs/2012/smsn/ngo/242.pdf.

IDESAM. 2008. "The Juma Sustainable Development Reserve Project: Reducing Greenhouse Gas Emissions from Deforestation in the State of Amazonas, Brazil." Accessed March 29, 2012. http://redd-database.iges.or.jp/redd/download/ project?id=19.

International Institute for Environment and Development. 2009. "REDD: Protecting climate, forests and livelihoods.” Accessed April 1, 2012. http://www.iied.org/reddprotecting-climate-forests-livelihoods.

Johnson, Toni. 2009. "Deforestation and Greenhouse-Gas Emissions." Council on Foreign Relations, updated December 21, 2009. Accessed April 3, 2012. http://www.cfr. org/natural-resources-management/deforestation-greenhouse-gas-emissions/ p14919.

Keller, Michael. Pesquisador Visitante, EMBRAPAa - CNPM, Scientist, Sustainable Landscapes Program, International Institute of Tropical Forestry \& International Programs, USDA Forest Service. Interview with Author. April 4, 2012.

Lele, Uma J. 2000. "Brazil: Forests in the Balance: Challenges of Conservation With Development.” World Bank Publications; July 1. http://lnweb9o.worldbank.org/oed/ oeddoclib.nsf/b57456d58aba40e585256ad400736404/d985594af1f1dfb185256 970007c1acc/\$FILE/BrazilCS.pdf.

Lerda, Daniela and Steve Zwick. 2009. Ecosystem Marketplace. "A Brief Tour of Brazilian Payments for Ecosystem Services.” Accessed April 1, 2012. http://www.ecosystemmarketplace.com/pages/dynamic/article.page.php?page_id=6524.

Luzar, Jeffery B. AAAS Science and Technology Policy Fellow, Office of Environmental Policy (OES/ENV), U.S. State Department. Interview with Author. April 6, 2012.

Nabuurs, G.J. et al, 2007: Forestry. In Climate Change 2007: Mitigation. Contribution of Working Group III to the Fourth Assessment Report of the Intergovernmental Panel on Climate Change. Edited by B. Metz, O.R. Davidson, P.R. Bosch, R. Dave, L.A. Meyer, Cambridge University Press, Cambridge, United Kingdom and New York, NY, USA. Accessed April 1, 2012. http://www.ipcc.ch/publications_and_ data/ar4/wg3/en/ch9.html.

Oestreicher, Jordan S., et al. 2009. "Avoiding deforestation in Panamanian protected areas: An analysis of protection effectiveness and implications for reducing emissions from deforestation and forest degradation.” Global Environmental Change Vol.19, Iss.2: 279-291. Accessed April 1, 2012. http://www.sciencedirect.com/science/article/pii/So959378009000144.

Prada, Paulo and Valerie Volcovici. 2012. "Rio+20 summit kicks off under cloud of criticism.” Reuters, June 20. Accessed August 23, 2012. http://www.reuters.com/article/2012/06/20/un-climate-idUSL1E8HK6U020120620.

Preston, Saskia. 2010. "Consumer Goods Forum plans to tackle deforestation and other key drivers of climate change." The Guardian, December 1. Accessed August 17, 2012. http://www.guardian.co.uk/sustainable-business/consumer-goods-forumdeforestation-climate.

TFD Review. 2010. "Investing in REDD-plus Consensus Recommendations on Frameworks for the Financing and Implementation of REDD-plus.” Accessed April 7, 
2013. http://unfccc.int/files/methods_science/redd/submissions/application/ pdf/redd_20100515_tfd_investing_in_redd.pdf.

The REDD Desk. 2011. "Brazil: An Overview from the REDD Countries Database." Accessed April 3, 2012. http://www.theredddesk.org/sites/default/files/resources/pdf/2011/brazil._an_overview_from_the_redd_countries_database_ may_2011.pdf.

Swedish Presidency of the European Union. n.d. "Building a post 2012 global climate regime: European Union CO-15 information sheet, Cutting forest $\mathrm{CO} 2$ emissions through action on deforestation in developing countries (REDD+).” PDF File. Accessed March 19, 2013. http://ec.europa.eu/clima/events/o013/info_sheet_ mitigation_dcs_final_en.pdf.

United Nations Permanent Forum on Indigenous Issues (UNFPII) Secretariat. 2011. "Indigenous Peoples and the UN-REDD Programme: An Overview." Paper submitted by the UN-REDD Programme at the International Expert Group Meeting on Indigenous Peoples and Forests, January 2011.www.un.org/esa/socdev/ unpfii/documents/EGM_IPF_UNREDD.doc.

United Nations. "Kyoto Protocol to the United Nations Framework Convention on Climate Change.” 1998. Accessed March 3, 2012. http://unfccc.int/resource/docs/ convkp/kpeng.pdf.

United Nations Development Group. 2010. "Multi-Partner Trust Fund Office - Fund Administration in Real Time.” Accessed April 4, 2012. http://mptf.undp.org/factsheet/fund/CCFoo?fund_status_month_to=\&fund_status_year_to=2010.

United Nations Framework Convention on Climate Change. 2009. "Copenhagen Climate Change Conference: The Copenhagen Accord.” Accessed March 30, 2012. http://unfccc.int/meetings/copenhagen_dec_2009/meeting/6295.php.

United Nations General Assembly. 2012. “The Future We Want.” Draft resolution submitted by the President of the General Assembly on July 24, 2012. Accessed August 23, 2012. http://www.uncsd2012.org/content/documents/370The\%20 Future\%20We\%2oWant\%2010Jan\%20clean\%20_no\%2obrackets.pdf.

United Nations News Centre. 2012. "Rio+20: \$513 billion pledged towards sustainable development.” Accessed August 23, 2012. http://www.un.org/apps/news/ story.asp? NewsID $=42312 \& \mathrm{Cr}=$ sustainable + development $\& \% 20 \mathrm{Cr} 1=\# . \mathrm{UPb}-$ huRooXTo.

United Nations Secretariat, 2010. "Report of the Secretary-General's High-Level Advisory Group on Climate Change Financing." Accessed March 20, 2013. http:// www.un.org/wcm/webdav/site/climatechange/shared/Documents/AGF_reports/AGF\%2oReport.pdf.

UN-REDD Programme. 2008 Framework Document. Collaborative Program Among Food and Agriculture Organization, United Nations Development Programme, and United Nations Environment Programme. Accessed March 30, 2012. http://www.un-redd.org/Portals/15/documents/publications/UN-REDD_ FrameworkDocument.pdf.

-- . 2011 Year in Review Report. "United Nations Collaborative Programme on Reducing Emissions from Deforestation and Forest Degradation in Developing Countries.” Accessed March 4, 2012. http://www.un-redd.org/PublicationsResources/tabid/587/Default.aspx.

- - . The UN-REDD Programme Strategy: 2011-2015. Accessed April 4, 2012. http:// www.un-redd.org/PublicationsResources/tabid/587/Default.aspx.

--—. National Programmes. Accessed April 2, 2012. http://www.un-redd.org/Partner_Countries/tabid/102663/Default.aspx. 
---. 2012. GO REDD+: A Participatory Approach to Design REDD Benefits. PDF File. http://www.google.com/url?sa=t\&rct=j\&q=\&esrc=s\&sourc e=web\&cd=4\&ved=oCFAQFjAD\&url=http\%3A\%2F\%2Fwww. unredd. net\%2Findex.php\%3Foption\%3Dcom_docman\%26task\%3Ddoc_downlo ad\%26gid\%3D7982\%26Itemid\%3D53\&ei=qNtJUfzCFOPD4AOqt4Bw\&u sg=AFQjCNEwhtVw577ZQdxQhW6Q4WfzdwKAtQ\&sig2=tt5kFYzX-lE6_ QOo7TH8wA\&bvm=bv.44011176,d.dmg.

Wallace, Scott. 2012. "Farming the Amazon." National Geographic, March 4. Accessed April 1, 2012. http://environment.nationalgeographic.com/environment/habitats/last-of-amazon/.

Zadek, Simon, Maya Forstater and Fernanda Polaco. 2010. "The Amazon Fund: Radical Simplicity and Bold Ambition.” Accessed March 4, 2012. http://www.zadek. net/wp-content/uploads/2010/o8/Amazon-Fund_Radical-Simplicity-andBold-Ambition_Working-Paper_November2010.pdf.

Helaina Matza is a second year Master of Public Administration student at The George Washington University, concentrating in global environmental management, program evaluation \& policy analysis. She earned a BA in international affairs from The George Washington University in 2007. She currently works for World Learning, an international NGO focused on empowering young leaders and sustainable capacity development globally. Helaina plans on dedicating her career to enhancing sustainable development programs and developing solutions environmental issues.

The author would like to thank Tanya Joshua, Anne Berry, Kristin Hubing, and Julia Watts for their support and tireless efforts in editing this paper. The author thanks Professor Joan Dudik-Gayoso for her mentorship and encouragement in submitting this article for publication. She also thanks Professor John Forrer for his direction and comments throughout the editing process. Finally the author would like to thank her friends and family for their support and patience as she pursues her professional and academic ambitions, especially Noah Cherry for his understanding and guidance throughout this journey. 